Bangladesh J. Zool. 42(2): 205-209, 2014

\title{
PROXIMATE COMPOSITION OF SALTED SMOKE-DRIED AND SALT-GARLIC TREATED SMOKE-DRIED CHAPILA (GUDUSIA CHAPRA; HAMILTON- BUCHANAN, 1822) FISH STORED AT ROOM TEMPERATURE
}

\author{
Mosarrat Nabila Nahid*, Gulshan Ara Latifa, Farzana Binte Farid \\ and Mohajira Begum ${ }^{1}$ \\ Department of Zoology, University of Dhaka, Dhaka 1000, Bangladesh,
}

\begin{abstract}
Proximate composition of chapila fish (Gudusia chapra) was determined using two different treatments of smoke-drying. In salt treated smoke-dried chapila (S-C), moisture, crude protein, lipid and ash contents were found $5.31 \%$, $46.47 \%, 29.05 \%$ and $19.92 \%$ respectively. The same parameters were $6.77 \%$, $45.24 \%, 30.52 \%$ and $18.71 \%$ respectively in case of salt-garlic treated smokedried chapila $(\mathrm{S}+\mathrm{G}-\mathrm{C})$ fish. During storage at room temperature $\left(26-32^{\circ} \mathrm{C}\right)$, the percentage of moisture was increased significantly whereas crude protein, lipid and ash contents were decreased. The values of moisture (\%) content were increased $9.91 \%$ ( $8^{\text {th }}$ months) in S-C and $10.74 \%$ (16 th months) in S+G-C respectively. The values of protein (\%) content were decreased $44.81 \%$ ( $8^{\text {th }}$ months) in $\mathrm{S}-\mathrm{C}$ and $42.66 \%$ (16 $6^{\text {th }}$ months) in S+G-C respectively. Values of fat and ash (\%) content were decreased $28.55 \%$ and $18.01 \%$ ( $8^{\text {th }}$ months) respectively in S-C and $28.75 \%$ and $17.34 \%\left(16^{\text {th }}\right.$ months) respectively in S+G-C. The overall study showed that the smoke cured fish treated with salt-garlic had longer shelf life and found better for preservation.
\end{abstract}

Key words: Chapila, Smoke-dried, Salt, Garlic, proximate composition.

\section{INTRODUCTION}

Chapila (Gudusia chapra, Hamilton-Buchanan, 1822) is a popular fish and consumed widely in different regions of Bangladesh. Among various preservation methods, smoking is very important in which excess water is removed and reducing the bacterial load. However the advantages of smoking of fishes are manifolds. Earlier authors (Olokor et al. 2007, Sengor et al. 2004, Eyo 2001, Horner 1997, Olley et al. 1988 and Clucas and Ward 1996) have also noted that apart from giving the product a desirable taste and odor, smoking provides a longer shelf-life through its anti-bacterial and anti-oxidative effect, lowering of $\mathrm{pH}$, imparting desirable colorations as well as accelerating the drying process and acting as antagonist to spoilage. Moreover, it reduces waste at times of bumper catches and permits storage for the lean season as well as increases protein availability to people throughout the year and makes fish easier to preserve, pack, transport and market.

*Author for correspondence: <mnabilanahid@yahoo.com>. ${ }^{1}$ IFST, BCSIR, Dhaka, Bangladesh. 
Salt $(\mathrm{NaCl})$ and Garlic (Allium sativum) are most common compounds and spice to enhance flavor in food, used in this experiment. The present study investigated the effects of salt and fresh garlic extract on proximate composition of smoke-dried Chapila which can extend the shelf-life of the fish product.

\section{MATERIAL AND METHODS}

This study was conducted between July 2012 to November 2013 at the Fish Technology Section of the Institute of Food Science and Technology (IFST) of Bangladesh Council of Scientific and Industrial Research (BCSIR), Dhanmondi, Dhaka. Fresh mature Chapila (Gudusia chapra) was collected from the fisherman of Meghna River early in the morning. Fish samples were transported to laboratory in sterile polythene bags and ice-box to avoid any microbial contamination.

Preparation for Smoke curing of the Experimental fish: The collected fishes were dressed, gutted and washed with clean water. The dressed fish samples were then weighed and prepared for smoke curing. The fish samples were divided into two groups. Group-A was treated with $30 \%$ salt solution while Group-B was treated with $30 \%$ salt and 30\% garlic solution, where fishes were dip for 15 minutes followed by draining. The fishes were smoked in improved traditional type of smoking kiln (Sarkar, 2005). The fish smoking kiln was operated by first loading tamarind wood chips and rice-husk into the heat chamber, preheating for some minutes and then loading the fish-samples onto removable wire mesh trays in its central chamber for the smoking process. The desired temperature $\left(75-80^{\circ} \mathrm{C}\right)$ was maintained manually. Smoking was done approximately for 4 hours. During the smoking fish samples were turned upside down in the middle period, to make the sample smooth and steady in texture and appearance. The smoked fishes showed characteristic attractive golden brown color and acceptable texture with smoky flavor, which was followed by cooling for 20-30 minutes at ambient temperature to make fish muscle compressed and facilitate to prevent breaking of smoked products. The cooled smoked fish samples were then packed and sealed in vacuum condition with marking taken in two different polythene bags (transparent). Two groups of smoke-dried fish product were then kept for storage at room temperature for further analysis of biochemical compositions.

During the storage period the two groups of smoke-dried samples were checked on two month interval basis.

Biochemical analysis: Analytical methods were applied for the determination of biochemical composition of the processed fish products on experimental basis. The moisture, fat and ash contents of the fish were determined by AOAC 
method (AOAC 1990) while the crude protein of the fish was determined by Micro-Kjeldhal method (Pearson 1999).

\section{RESULTS AND DISCUSSION}

The proximate composition, moisture, protein, fat, ash of fresh Chapila fish was $76.41,10.53,11.62$ and $1.50 \%$, respectively. Fresh sample presented a high moisture and low protein content, similar to previous reported by Eyo (1998). In the corresponding, during smoke-drying, the percentage of moisture content decreased and protein, lipid and ash content increased significantly $(\mathrm{p}<0.05)$ due to water loss. This observation is in agreement with the findings of Bhuiyan et al. (1986) in Atlantic mackerel and Unlusayin et al. (2001) in European eel, pike perch and rainbow trout.

After storing at room temperature for $8^{\text {th }}$ month it was found that the salted smoke-dried chapila fish product has some problems of fungal attack. It may be due to the effect of season where the temperature and relative humidity may be high in room than outside. Similar result was also found in the work of Daramola (2007). While the salt and garlic treated fish were found to be in their normal characteristics up to the $16^{\text {th }}$ months. Because of antifungal effect of garlic, there is no fungal attack shown on salt and garlic treated smoke-dried chapila.

During storage at room temperature, percent of moisture varied from $5.31 \%$ (o day) to $9.91 \%$ ( $8^{\text {th }}$ month) for salted smoke-dried chapila (Table 1 ) and $6.77 \%$ (0 day) to $10.74 \%$ ( $16^{\text {th }}$ month) for salt and garlic treated smoke-dried chapila (Table 2). Faturoti (1985) showed that the gutted smoke dried fish samples of African cat fish (Clarias gariepinus) had moisture content as 6.27 to $10.92 \%$ which is similar with present study.

Table 1. Changes in proximate composition of salted smoke-dried chapila fish during storage at room temperature (Shelf life 8 month).

\begin{tabular}{cllll}
\hline Storage period (month) & Moisture (\%) & Protein (\%) & Fat (\%) & Ash (\%) \\
\hline 0 & 5.31 & 46.47 & 29.05 & 19.92 \\
2 & 6.51 & 46.01 & 28.92 & 19.44 \\
4 & 7.52 & 45.73 & 28.78 & 19.02 \\
6 & 8.61 & 45.09 & 28.69 & 18.71 \\
8 & 9.91 & 44.81 & 28.55 & 18.01 \\
\hline
\end{tabular}

Protein (\%) varied from $46.47 \%$ (0 day) to $44.81 \%$ ( $8^{\text {th }}$ month) for salted smoke-dried chapila and $45.24 \%$ (0 day) to $42.66 \%$ (16 $6^{\text {th }}$ month) for salt and garlic treated smoke-dried chapila. In storage condition, the protein content decreased significantly with time due to water soluble protein diffused out to the 
surrounding for exosmosis (Hassan et al. 2013). Fat (\%) changed from $29.05 \%$ (0 day) to $28.55 \%$ ( $8^{\text {th }}$ month) for salted smoke-dried chapila and $30.52 \%$ (0 day) to $28.75 \%$ (16 ${ }^{\text {th }}$ month) for salt and garlic treated smoke-dried chapila. Usually moisture and fat contents in fish flesh are inversely related and there sum is approximately $80 \%$ (FAO, 1999). This inverse relationship was also well defined in this experiment. Ash contents (\%) dropped from $19.92 \%$ (0 day) to $18.01 \%$ ( $8^{\text {th }}$ month) for salted smoke-dried chapila and $18.71 \%$ (0 day) to 17.34 $\%\left(16^{\text {th }}\right.$ month $)$ for salt and garlic treated smoke-dried chapila. The ash content changes with the time of storage due to absorbance of moisture and loss of protein (Hassan et al. 2013).

Table 2. Changes in proximate composition of salt and garlic treated smoke-dried chapila fish during storage at room temperature (Shelf life 16 month).

\begin{tabular}{crrrc}
\hline Storage period (Month) & Moisture (\%) & Protein $(\%)$ & \multicolumn{1}{c}{ Fat $(\%)$} & \multicolumn{1}{c}{ Ash $(\%)$} \\
\hline 0 & 6.77 & 45.24 & 30.52 & 18.71 \\
2 & 6.98 & 45.01 & 30.12 & 18.64 \\
4 & 7.25 & 44.98 & 30.02 & 18.49 \\
6 & 7.64 & 44.71 & 29.89 & 18.31 \\
8 & 7.88 & 44.59 & 29.77 & 18.15 \\
10 & 8.87 & 44.01 & 29.51 & 18.01 \\
12 & 9.69 & 43.87 & 29.18 & 17.98 \\
14 & 10.55 & 43.11 & 28.91 & 17.72 \\
16 & 10.74 & 42.66 & 28.75 & 17.34 \\
\hline
\end{tabular}

Significant statistical differences were found between the initial product and end product after storage period. There were positive significant influences of drying on the proximate compositions of chapila fish making it nutritionally suitable for all. This study has shown that garlic has some antioxidative and antimicrobial properties which can retard the growth of micro-organisms and thus extend the shelf life of salt-garlic smoke-dried chapila fish product than salted smoke-dried chapila fish product.

\section{LITERATURE CITED}

AOAC. 1990. Official Methods of Analysis. Association of Official Agricultural Chemists W. Horwitz (Editor) $12^{\text {th }}$ ED. Washington. D.C.

BHUIYAN, A.K.M. RATNAYAKE, W.M.N. and ACKMAN, R.G. 1986. Effect of smoking on the proximate composition of Atlantic mackerel (Scomber scombrus). J. Food Sci. 51: 327-329.

CLUCAS, I.J, and WARD, A.R. 1996. Post Harvest Fisheries Development. A Guide to Handling , Preservation, Processing and Quality. Chatham Maritime, Kent ME4TB, United Kingdom. pp. 665.

DARAMOLA, J.A. FASAKIN, E.A. and ADEPARUSI, E.O. 2007. Changes in physicochemical and sensory characteristics of smoke-dried fish species stored at ambient temperature. African J. of Food Ag. Nut. And Dev. 7 (6): 453-459. 
EYO, A.A. 2001. Fish processing Technology in the Tropics. Published by National Institute for Freshwater Fisheries Research (NIFFR), P.M.B. 6006, New Bussa, Niger State.

EYO, A.A. 1998. Shelf-life of Moon fish (Citharinus citharus) and Tumk Fish (Mormyrus rume) during storage at ambient temperature and on Ice. FAO Fisheries Report No. 574: 35-37.

FAO, 1999. World production of fish, crustaceans and mollusks by major fishing areas. Fisheries Information Data and Statistics unit (FIDI), Fisheries Department, FAO Rome. 33 pp.

FATUROTI, E.O. 1985. Biological utilization of sun-dried and smoked African cat fish (Chrysichthys nigrodigitus). Nutritative Reports International, Rwp. of Wildlife and Fisheries Management, Univ. of Ibadan, Nigeria. 30(6): 1395-1400.

HASSAN, M.N. RAHMAN, M. HOSSAIN, M.M. NOWSAD, A.A.K.M. and HOSSAIN, M.B. 2013. PostHarvest Loss and Shelf Life of Traditionally Smoked Shrimp Products Produced in Bangladesh. World J. of Fish and Marine Sci. 5(1):14-19.

HORNER, W.F.A. 1997. Preservation of Fish by Curing (Drying, Salting and Smoking). In Fish processing Technology 2nd ed. Edited by G.M. Hall. 34-36.

OLLEY, J. DOE, P.E. and HERUWATI, E.S. 1988. The influence of drying and smoking on the nutritional properties of fish. In Burth JR (ed); An Introd. Overview in fish smoking and drying. Elsevier, London. 1-14.

OLOKOR, J.O. IHUAHI, J.A. OMOJOWO, F.S. FALAYI, B.A. and ADELOWO, E.A. 2007. Handbook of Practical Fisheries Technology. Published by Fisheries Technology Dvision, National Institute for Freshwater Fisheries Research (NIFFR), P.M.B 6006, New Bussa, Niger State. 22-29.

PEARSON, D. 1999. Pearson's composition and analysis of foods. University of Reading.

SARKAR, G. Chakraborty, S.C. Islam, M.N. 2005. A study on the shelf-life of smoked thai pangus (Pangasius hypophthalmus). M.Sc. Thesis submitted to Bangladesh Agricultural University, Mymensingh. 71pp.

SENGOR, G.F. KALAFATOGLU, H. GUN, H. and 2004. The determination of Microbial flora, water activity and chemical analysis in smoked Mussels (Mytilus galloprovincialis, L.) Tunk. J. Vet. Anim. Sci. 28:793-797.

UNLUSAYIN, M. KALELI, S. and GULYAVUZ, H. 2001. The determination of flesh productivity and protein components of some fish species after hot smoking. J. Sci. Food Agric. 81: 661-664. 